Article

\title{
A Preliminary Spatial Analysis of the Association of Asthma and Traffic-Related Air Pollution in the Metropolitan Area of Calgary, Canada
}

\author{
Stefania Bertazzon ${ }^{1, *}$, Caitlin Calder-Bellamy ${ }^{2}$, Rizwan Shahid $\left.{ }^{3}{ }^{(}\right)$, Isabelle Couloigner ${ }^{1}(\mathbb{D}$ and \\ Richard Wong ${ }^{1}$ \\ 1 Department of Geography, University of Calgary, Calgary, AB T2N 1N4, Canada; icouloig@ucalgary.ca (I.C.); \\ richard.wong1@ucalgary.ca (R.W.) \\ 2 Cumming School of Medicine, University of Calgary, Calgary, AB T2N 1N4, Canada; \\ caitlin.calderbellam@ucalgary.ca \\ 3 Primary Health Care, Alberta Health Services, Calgary, AB T2W3N2, Canada; \\ rizwan.shahid@albertahealthservices.ca \\ * Correspondence: bertazzs@ucalgary.ca
}

Received: 4 September 2020; Accepted: 1 October 2020; Published: 8 October 2020

\begin{abstract}
We performed a preliminary spatial analysis to assess the association of asthma emergency visits $(\mathrm{AEV})$ with ambient air pollutants $\left(\mathrm{NO}_{2}, \mathrm{PM}_{2.5}, \mathrm{PM}_{10}\right.$, Black Carbon, and VOCs) over Calgary, Canada. Descriptive analyses identify spatial patterns across the city. The spatial patterns of AEV and air pollutants were analyzed by descriptive and spatial statistics (Moran's I and Getis G). The association between AEV, air pollutants, and socioeconomic status was assessed by correlation and regression. A spatial gradient was identified, characterized by increasing AEV incidence from west to east; this pattern has become increasingly pronounced over time. The association of asthma and air pollution is consistent with the location of industrial areas and major traffic corridors. AEV exhibited more significant associations with BTEX and $\mathrm{PM}_{10}$, particularly during the summer. Over time, AEV decreased overall, though with varying temporal patterns throughout Calgary. AEV exhibited significant and seasonal associations with ambient air pollutants. Socioeconomic status is a confounding factor in AEV in Calgary, and the AEV disparities across the city are becoming more pronounced over time. Within the current pandemic, this spatial analysis is relevant and timely, bearing potential to identify hotspots linked to ambient air pollution and populations at greater risk.
\end{abstract}

Keywords: air pollution; asthma; spatial analysis; traffic-related air pollution; environmental health

\section{Introduction}

Asthma is a chronic respiratory disease characterized by inflammation and narrowing of air passages [1]. Asthmatic symptoms include wheezing, shortness of breath, and chest tightness [2]. Although common worldwide, asthma prevalence is higher in developed western countries, such as Canada, rather than in developing countries [1]. As of 2018, approximately $12 \%$ of Canadians (i.e., 3 million people) and 12\% of Albertans have been diagnosed with asthma [3,4]. Asthma prevalence is increasing in Alberta [5], where the asthma incidence rate was highest in children aged 1 to 14 [6]. Children are more susceptible to asthma onset, likely a result of a less developed immune system, smaller lung passages, increased exposure to outdoor pollutants, and increased pollutant inhalation per body weight [7].

Urban and metropolitan areas often have higher asthma prevalence than rural areas, potentially due to increased exposure to ambient air pollutants, as elevated pollutant levels have led to surges in emergency visits for people with asthma and those with asthmatic symptoms [7-9]. Individuals 
with a low-income subsidy or those of lower socioeconomic status are more likely to experience increased exposure to higher concentrations of air pollutants, thus further increasing the risk of asthma exacerbation [10-12]. Children of families with lower socioeconomic status are associated with asthma prevalence and incidence and asthma exacerbation [13-15].

Traffic-related air pollutants (TRAP), notably nitrogen dioxide $\left(\mathrm{NO}_{2}\right)$ and particulate matter with a diameter less than 2.5 micrometers $\left(\mathrm{PM}_{2.5}\right)$, have been widely researched and are known to both exacerbate asthma and lead to decreased lung function, increased risk of asthma onset, and increased asthma-related hospitalizations [8,9,16-21]. Many studies have noted that consistent exposure to elevated levels of $\mathrm{NO}_{2}$ and $\mathrm{PM}_{2.5}$ can decrease lung function and lead to asthmatic symptoms such as wheezing through airway inflammation and oxidative stress [21-23]. Other ambient air pollutants, such as particulate matter with a diameter less than 10 micrometers $\left(\mathrm{PM}_{10}\right)$, BTEX (VOCs), and black carbon (BC), have also been associated with decreased lung function, asthma exacerbation, and asthma onset [24,25]. $\mathrm{PM}_{10}$ often refers to pollutants and allergens such as pollen, dust, and mold [26]. BTEX refers to four volatile organic compounds (VOCs): benzene, toluene, ethylbenzene, and xylene [27]. While BTEX can exist naturally in crude oil and in forest fire gas emissions, man-made BTEX sources include diesel fuel combustion, aircraft emissions, and cigarettes; gas stations are a common site of BTEX exposure $[27,28]$. BC refers to sooty black material, often resulting from diesel fuel combustion, biomass combustion, or coal burning [29]. BC is one component of $\mathrm{PM}_{2.5}$ [29]. Increased exposure to ambient air pollutants increases the risk of asthma exacerbation and/or asthma onset [16].

While many studies analyze the effects of proximity to common TRAPs, such as $\mathrm{NO}_{2}$ and $\mathrm{PM}_{2.5}$ [20], fewer focus on the seasonal effects of other ambient air pollutants, especially $\mathrm{PM}_{10}$, BTEX, and $\mathrm{BC}[17,30,31]$. Moreover, many studies identify the proximity to TRAP in relation to home residence, whereas individuals tend to spend time outside their residence; for example, most children spend a large amount of time at school and/or daycare, as well as outside on, or close to, school grounds [20]. Because people are exposed to air pollution beyond their residential environment, it is important to assess the possible associations between asthma exacerbation and the spatial pattern of ambient air pollutants.

Spatially detailed air pollution data are rarely available and monitoring networks are sparsely installed, mostly due to the high costs associated with air monitoring. This study relies on fine-scale, i.e., dissemination block level [32], air quality estimates, obtained through land use regression (LUR) models on data from two monitoring campaigns conducted by our group in collaboration with Health Canada over the metropolitan area of Calgary, with deployment of up to 100 monitoring stations [33]. As owners of the 2010-2011 and 2015-2016 LUR models, we can affirm with certainty that no other study conducted has analyzed the association between asthma and air pollution over space in the Calgary metropolitan area.

The objective of this study is to analyze the association between asthma exacerbation and ambient concentrations of $\mathrm{NO}_{2}, \mathrm{PM}_{2.5}, \mathrm{PM}_{10}, \mathrm{BTEX}$, and BC in Calgary, Alberta. The spatial analytical approach and the use of spatially detailed estimates of air pollution constitute the primary novelty of our work.

\section{Study Region, Data, and Methods}

Calgary is the third most populous Canadian city and the fourth largest metropolitan area, with a population of over 1.5 million as of 2019 [34,35]. It is situated east of the Rocky Mountains, in a transition zone between the Rockies' Foothills and the Canadian prairies, where the Bow and Elbow Rivers meet [36,37]. The city spans $848 \mathrm{~km}^{2}$ at $1048 \mathrm{~m}$ above sea level $[35,36]$. Because of its location, Calgary experiences many Chinook winds, bringing dry and warm winds to the city; Calgary's average wind speed is $14.2 \mathrm{~km}$ per hour-one of the highest average wind speeds in Canada [38]. Calgary's dry climate results in mild summer temperatures and cold winters [36]. The average daily summer temperature is $15.2{ }^{\circ} \mathrm{C}$ and the average daily winter temperature is $-7.5^{\circ} \mathrm{C}$, although temperatures can vary to extremes [36]. Calgary was designed using segregated land use, with clear separation between residential, commercial, and industrial areas. The eastern part of the city primarily includes 
industrial areas, including an international airport, whereas the western part of the city is primarily residential [39]. In Calgary, the prevailing wind direction is often seasonally dependent [40]. In the winter months, Calgary experiences more northerly and northwesterly winds which blow air towards the south and the southeast areas of the city [40]. In the summer months, Calgary experiences more westerly or southwesterly winds which blow air towards the east and the northeast areas of the city [40].

Asthma prevalence and emergency room visit data were retrieved from the Alberta Health Interactive Tool [41]. Two asthma-related variables were available: Age-Standardized Asthma Prevalence (ASAP), along with Age-Standardized Asthma Prevalence Rate (ASAPR), and Age-Standardized Emergency Visits (AEV), along with Age-Standardized Emergency Visit Rate (AEVR). None of these variables were available for specific age groups; for this reason, this study cannot specifically analyze children. Of these variables, AEV was chosen as a proxy for asthma exacerbation [9]. The variables of interest were extracted for each of the 16 Local Geographic Areas (LGA) within the Calgary zone, over the entire study period (2008-2018). LGAs are the smallest geographical area defined by the Government of Alberta primarily for health service planning and management (Figure 1). Additional indicators of population and socioeconomic status (SES) were also drawn from the Alberta Health Interactive Tool [41].

Previous studies conducted by our group yielded land use regression (LUR) estimates of air quality at fine scale (see Figure 3). Air quality monitoring campaigns were conducted during the summer and winter of 2010-2011 and of 2015-2016, yielding summer and winter models, respectively, for each campaign [33,42-44]. For both the 2010-2011 and 2015-2016 campaigns, LUR models were computed for nitrogen dioxide $\left(\mathrm{NO}_{2}\right)$ and particulate matter $\left(\mathrm{PM}_{2.5}\right.$ and $\left.\mathrm{PM}_{10}\right)$, among other pollutants. Additionally, during the 2015-2016 campaign, LUR models for BTEX and black carbon (BC) were computed. LUR models compute regression coefficients for a set of predictors, for a given pollutant and for a given sample. Spatiotemporal LUR models of $\mathrm{NO}_{2}$ are discussed in previously published work $[33,45]$. Despite differences across monitoring campaigns, and an overall slight downward trend in pollution levels, these studies show that pollutants exhibit a consistent spatial pattern over the 5 -year interval between campaigns. Given these results, the summer 2015 and winter 2016 LUR estimates for $\mathrm{NO}_{2}, \mathrm{PM}_{2.5}$, and $\mathrm{PM}_{10}$ are used in this study; the only available LUR estimates for BC and BTEX are those for summer 2015 and winter 2016. These estimates will approximate summer and winter pollution at fine scale over the entire study period.

Statistical analyses, both standard and spatial, were conducted in the statistical computing software R. Standard analysis includes descriptive statistics and Shapiro-Wilk normality tests on all the variables. Correlation analysis was used to test the association between asthma and pollution variables; as most pollutants exhibit non-normal distributions, the Spearman test was used. A $t$-test analysis served to analyze the differences in asthma visits across years.

Spatial statistics include clustering (Getis G) and spatial autocorrelation (Moran's I) tests. Getis $G$ evaluates the degree of spatial clustering of a variable: significant positive values of the $z$-score associated with $\mathrm{G}$ indicate clustering of high values within a given distance, while significant negative z-scores indicate clustering of low values; non-significant z-scores indicate spatial randomness [46]. Spatial autocorrelation evaluates whether a variable exhibits self-similarity over short distances. Moran's I spatial autocorrelation index ranges from -1 , which indicates perfect negative spatial autocorrelation (dispersion, or regular pattern), to +1 , indicating perfect positive spatial autocorrelation (tendency to clustering); 0 indicates uncorrelation between similarity and distance-that is, spatial randomness [47]. The two measures (clustering vs. spatial autocorrelation) are often considered complementary: for example, positive spatial autocorrelation indicates a tendency toward clustering, but it does not specify whether it is a cluster of low or high values, whereas this indication is provided by Getis G. 


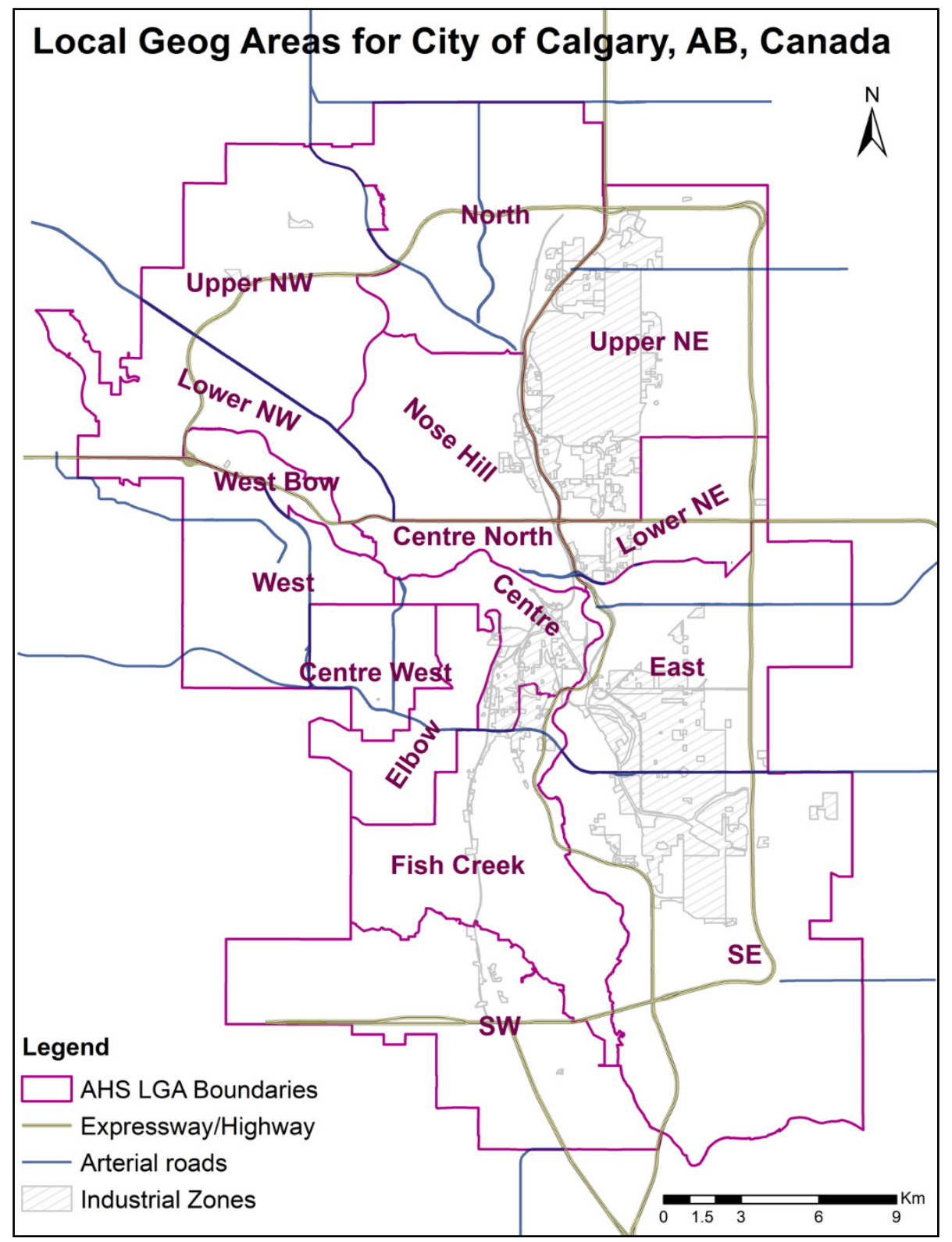

Figure 1. Study area overview showing the Alberta Health (AHS) Local Geographic Areas (LGAs).

Further regression analysis was conducted to assess the association of AEV with pollutants [48]. Ideally, a multivariate regression would test the association of multiple pollutants simultaneously; however, due to the low sample size (16 LGAs), the number of predictors was kept to a minimum. A regression was run for each pollutant, including, as predictors, one pollutant and population for $\mathrm{AEV}$, and for AEVR, low income was included to adjust for socioeconomic status. The latter was not included in the AEV regression in order to avoid using too many predictors in each model. Prior to running each regression, the correlation between each pollutant and the socioeconomic status indicator was tested in order to avoid potential multicollinearity [48]. In light of the spatial autocorrelation observed in AEV, spatially autoregressive models were considered [49].

ArcGIS software was used to for all the maps in this paper.

\section{Results}

Figure 1 provides an overview of the metropolitan area of Calgary. 
Figure 2 summarizes the spatial and temporal trend of AEVR. For each LGA, the map presents a histogram of age-standardized asthma emergency visit rate over the 11-year sample period. The complete set of maps and descriptive statistics for AEV, as well as AEVR, is reported in Table S1.

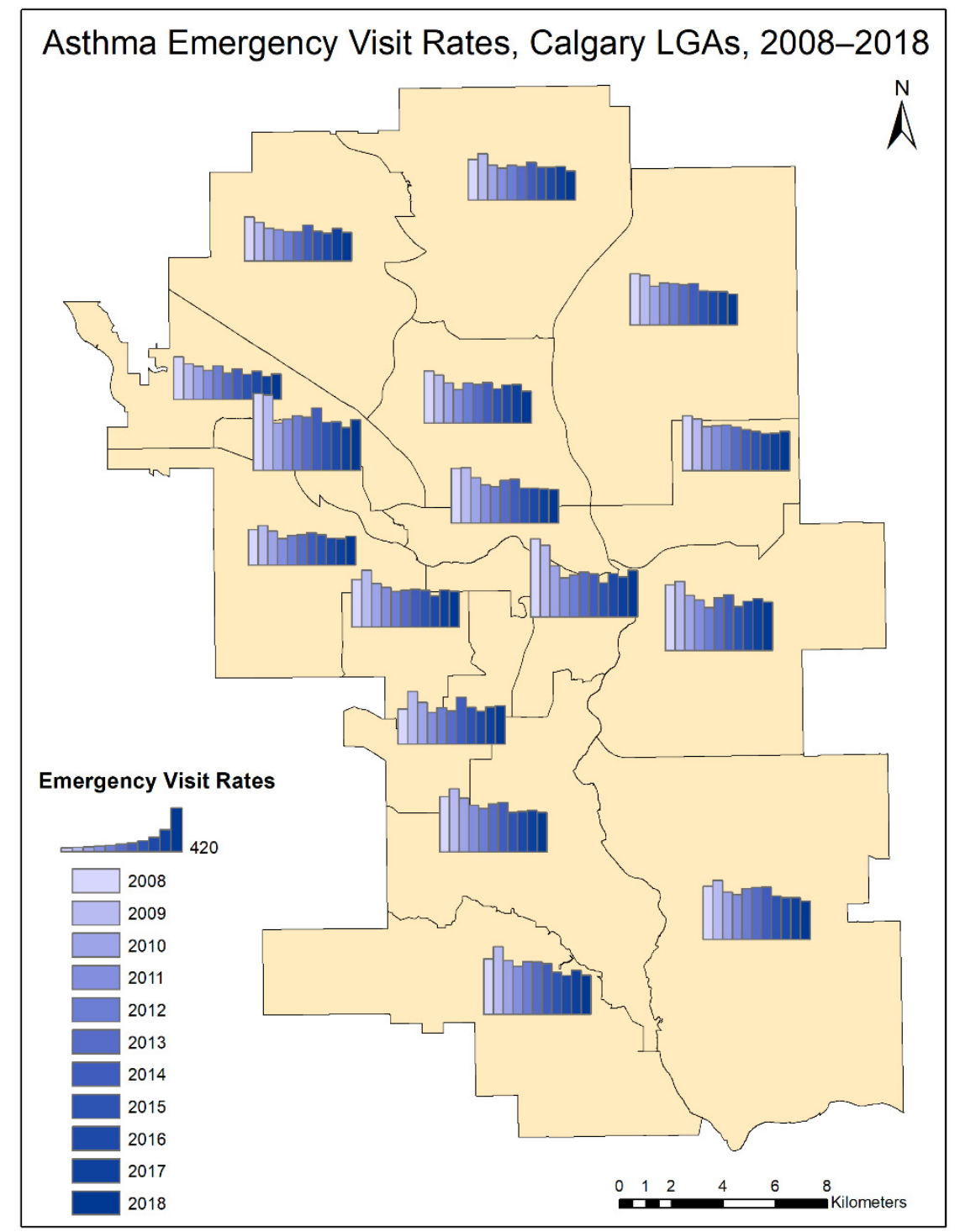

Figure 2. Histograms representing the yearly distribution (2008-2018) of Asthma Emergency Visit Rates (AEVR) for the Calgary LGAs (Local Geographic Areas).

Descriptive statistics of AEVR over 16 LGAs for each sample year are presented in Table 1.

Table 1. Descriptive statistics for age-standardized emergency visit rate by year.

\begin{tabular}{cccccccccccc}
\hline Year & $\mathbf{2 0 0 8}$ & $\mathbf{2 0 0 9}$ & $\mathbf{2 0 1 0}$ & $\mathbf{2 0 1 1}$ & $\mathbf{2 0 1 2}$ & $\mathbf{2 0 1 3}$ & $\mathbf{2 0 1 4}$ & $\mathbf{2 0 1 5}$ & $\mathbf{2 0 1 6}$ & $\mathbf{2 0 1 7}$ & $\mathbf{2 0 1 8}$ \\
\hline Min. & 375.22 & 381.30 & 352.66 & 283.96 & 314.41 & 280.88 & 327.33 & 269.88 & 286.47 & 246.93 & 274.96 \\
Mean & 566.23 & 591.22 & 467.70 & 422.65 & 435.30 & 441.52 & 471.50 & 392.82 & 393.20 & 399.67 & 393.29 \\
Max. & 839.00 & 810.94 & 593.65 & 549.35 & 587.23 & 571.44 & 669.66 & 516.43 & 531.83 & 560.67 & 547.85 \\
Std. Dev. & 135.40 & 130.20 & 81.84 & 85.78 & 83.10 & 97.36 & 93.10 & 64.47 & 74.21 & 75.63 & 80.99 \\
S-W & 0.92 & 0.97 & 0.94 & 0.94 & 0.96 & 0.94 & 0.97 & 0.98 & 0.96 & 0.97 & 0.94 \\
$(\boldsymbol{p}$-value $)$ & $(\mathrm{ns})$ & $(\mathrm{ns})$ & $(\mathrm{ns})$ & $(\mathrm{ns})$ & $(\mathrm{ns})$ & $(\mathrm{ns})$ & $(\mathrm{ns})$ & $(\mathrm{ns})$ & $(\mathrm{ns})$ & $(\mathrm{ns})$ & $(\mathrm{ns})$ \\
\hline
\end{tabular}


When averaged between 2008 and 2018, the LGA with the lowest mean asthma emergency visit rate was Lower NW, with a rate of 325.06/100,000 (Figure 2). The LGA with the highest mean asthma emergency visit rate was West Bow, with a rate of 597.05/100,000 (Figure 2). While the emergency visit rate decreases for all LGAs over time, each LGA exhibits a distinct temporal trend throughout the study period (Figure 2). ASEVR exhibits an overall decline from 2008 to 2018 (Table 1). $t$-tests of the difference in the means yielded no significant results, suggesting that none of the sample years was significantly different from the rest of the period. All variables follow a normal distribution according to the Shapiro-Wilk test.

Clustering analysis (Getis G) did not yield any significant results, and therefore it is not presented. Conversely, spatial autocorrelation analysis (Moran's I), presented in Table 2, not only yielded significant results over the entire period, but the index values exhibited a tendency to increase over time.

Table 2. Spatial autocorrelation of Asthma Emergency Visits (AEV).

\begin{tabular}{cccccccccccc}
\hline Year & $\mathbf{2 0 0 8}$ & $\mathbf{2 0 0 9}$ & $\mathbf{2 0 1 0}$ & $\mathbf{2 0 1 1}$ & $\mathbf{2 0 1 2}$ & $\mathbf{2 0 1 3}$ & $\mathbf{2 0 1 4}$ & $\mathbf{2 0 1 5}$ & $\mathbf{2 0 1 6}$ & $\mathbf{2 0 1 7}$ & $\mathbf{2 0 1 8}$ \\
\hline Moran I & 0.50 & 0.64 & 0.60 & 0.67 & 0.67 & 0.70 & 0.71 & 0.67 & 0.64 & 0.68 & 0.63 \\
z(I) & 1.90 & 2.38 & 2.28 & 2.46 & 2.46 & 2.57 & 2.60 & 2.48 & 2.42 & 2.51 & 2.36 \\
$p$-value & $\left(^{*}\right)$ & $\left(^{* *}\right)$ & $\left(^{* *}\right)$ & $\left(^{* * *}\right)$ & $(* *)$ & $(* *)$ & $(* * *)$ & $(* *)$ & $(* *)$ & $(* *)$ & $(* *)$ \\
\hline
\end{tabular}

p-value: $\left.\left.{ }^{* * *}\right)[<0.01] ;{ }^{* *}\right)[0.01-0.05] ;\left(^{*}\right)[0.05-0.1] ;($ ns) $[>0.1]$ not significant.

Figure 3 shows the spatial distribution of the pollutants analyzed according to summer and winter LUR estimates. Spatial autocorrelation was seen in all pollutants except PM 10 . BTEX was significantly autocorrelated in the summer months but not in the winter months. Spatial autocorrelation exhibited overall greater values in the summer months for $\mathrm{BC}$ and $\mathrm{NO}_{2}$, whereas $\mathrm{PM}_{2.5}$ remained uniform throughout the seasons (Table 2).

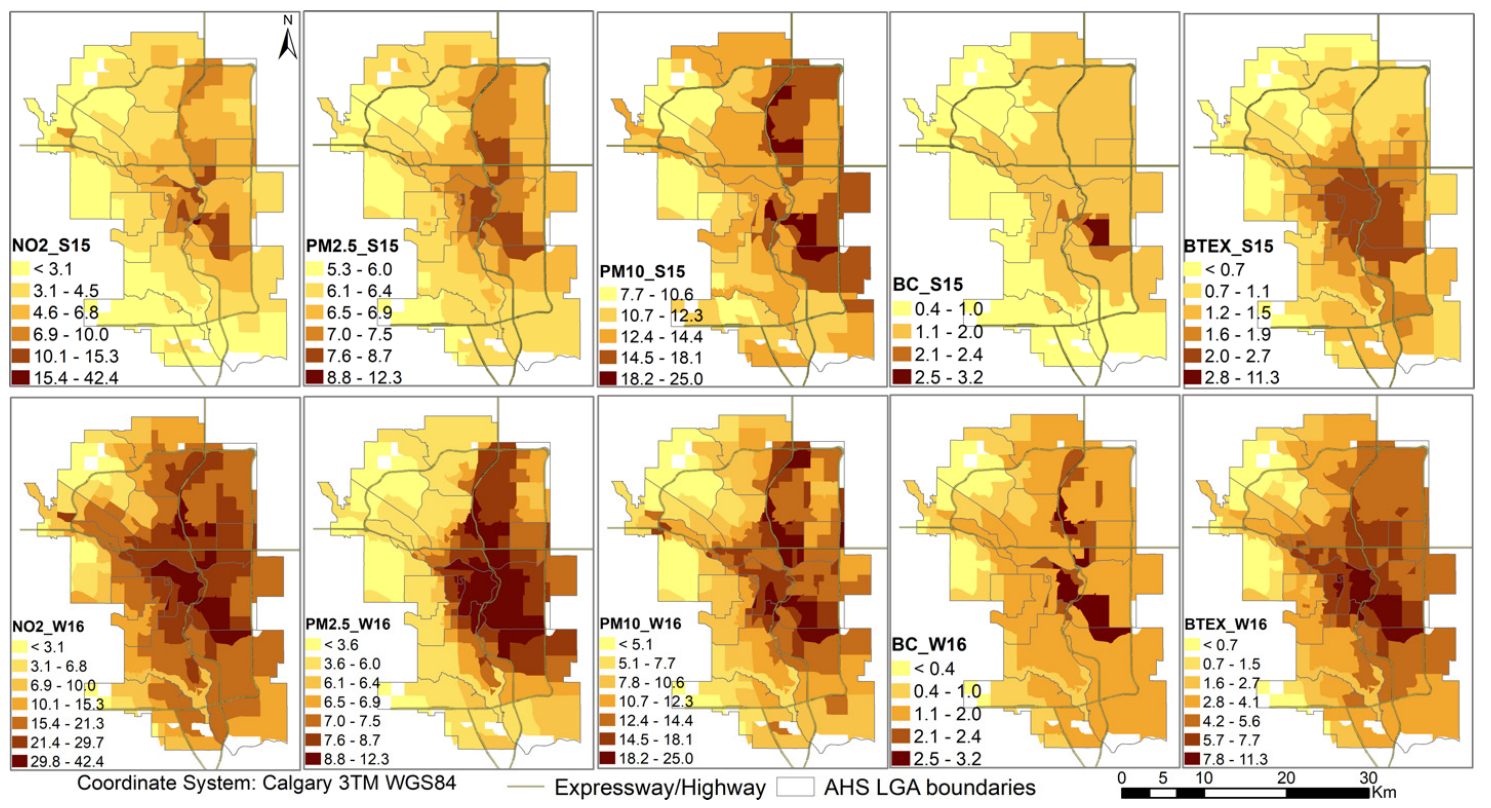

Figure 3. Air pollutant estimates over Calgary in summer (S15) and winter (W16).

Figure 4 illustrates the prevailing winds over Calgary, represented by windrose diagrams based on historical wind data [50], for the months of August and January-February-that is, the months when air quality campaigns were conducted. 
CYYC: Calgary International, Alta.

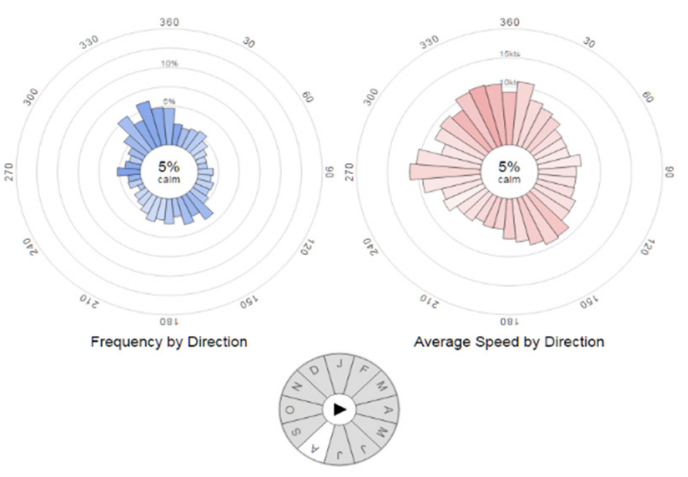

CYYC: Calgary International, Alta.

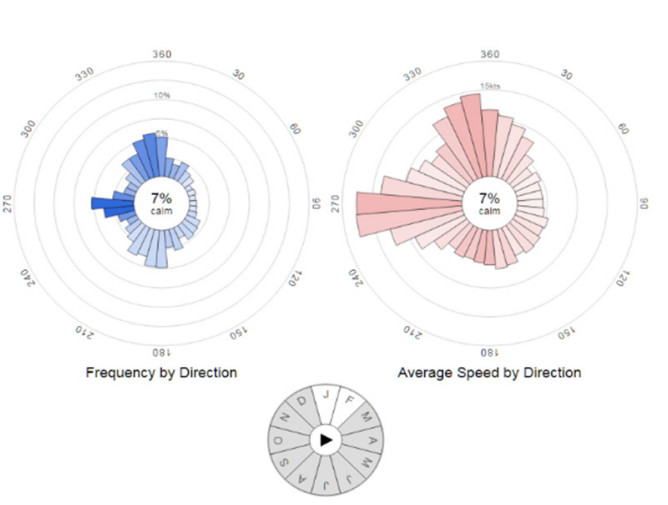

Figure 4. Calgary summer and winter prevailing winds (from http://windhistory.com [50]).

Figure 3 further shows that both BTEX and $\mathrm{PM}_{10}$ are more highly concentrated during the winter months than the summer months (Figure 3). $\mathrm{NO}_{2}$ is also more highly concentrated during the winter months; conversely, $\mathrm{PM}_{2.5}$ is more highly concentrated in the summer months and $\mathrm{BC}$ concentrations are quite even throughout the seasons. During the winter months, $\mathrm{NO}_{2}, \mathrm{PM}_{2.5}, \mathrm{PM}_{10}$, and $\mathrm{BC}$ are generally all more concentrated in the NE quadrant of the city, particularly the Upper NE, Lower NE, and East LGAs (Figure 3). In the summer months, however, $\mathrm{PM}_{10}$ and BTEX are more evenly distributed throughout the city (Figure 3). The lowest pollutant concentrations are in the NW quadrant of the city, particularly the Upper NW and West LGAs (Figure 3).

The spatial pattern of AEV and AVR for each sample year is shown in Table S1, accompanied by descriptive statistics.

The Spearman correlation between AEVR and each of the pollutants considered is summarized in Table 3 for each year and season.

$\mathrm{NO}_{2}, \mathrm{PM}_{10}, \mathrm{BC}$, and BTEX are more often significantly correlated to asthma emergency visit rates during the summer, whereas $\mathrm{PM}_{2.5}$ exhibits more frequent significant correlations in the winter (Table 3). Of the pollutants examined, BTEX exhibits the most frequent and significant correlations with asthma emergency visit rates (seven of the 22 seasons during the study period), followed by $\mathrm{PM}_{10}$ (three seasons), $\mathrm{PM}_{2.5}$ and $\mathrm{NO}_{2}$ (two seasons), and $\mathrm{BC}$ (one season) (Table 3). The summer of 2016 exhibits the highest number of significant correlations (all the pollutants, with the exception of $\mathrm{PM}_{2.5}$ ) of the whole study period (Table 3).

Correlation across potential regression predictors was not run across pollutants, as each regression would include only one. Correlation between population and each pollutant yielded non-significant results. Conversely, the correlation between low income and each pollutant was consistently between 0.40 (Table 4) and 0.68 ; these correlations, though significant, were considered sufficiently low to allow for the inclusion of both predictors in each regression.

For two dependent variables, AEV and AEVR, on five pollutants, each over two seasons, over the 11-year study period, 440 regressions were computed. Such a large number of regressions is not reported. As well, the regressions yielded mixed results, albeit overall consistent with the correlations (Table 3). The pollutant that exhibited most frequent significant associations was BTEX, followed by $\mathrm{PM}_{10}, \mathrm{PM}_{2.5}, \mathrm{BC}$, and $\mathrm{NO}_{2}$. From the temporal point of view, 2016 exhibited the largest number of significant regressions. Therefore, we report the complete set of 10 regressions for 2016 in Table S2. 
Table 3. Correlation of Asthma Emergency Visit Rate (AEVR) with pollutants in summer (_S) and winter (_W) with significance level ${ }^{1}$.

\begin{tabular}{|c|c|c|c|c|c|c|c|c|c|c|}
\hline Pollutants & NO2_S & NO2_W & PM2.5_S & PM2.5_I & W PM10_S & PM10_W & BC_S & BC_W & BTEX_S & BTEX_W \\
\hline AEVR_08 & $\begin{array}{l}0.32 \\
\text { (ns) }\end{array}$ & $\begin{array}{l}0.22 \\
\text { (ns) }\end{array}$ & $\begin{array}{l}0.31 \\
\text { (ns) }\end{array}$ & $\begin{array}{l}0.30 \\
\text { (ns) }\end{array}$ & $\begin{array}{l}0.37 \\
\text { (ns) }\end{array}$ & $\begin{array}{l}0.11 \\
\text { (ns) }\end{array}$ & $\begin{array}{l}0.35 \\
\text { (ns) }\end{array}$ & $\begin{array}{l}0.25 \\
\text { (ns) }\end{array}$ & $\begin{array}{l}0.35 \\
\text { (ns) }\end{array}$ & $\begin{array}{l}0.29 \\
\text { (ns) }\end{array}$ \\
\hline AEVR_09 & $\begin{array}{l}0.19 \\
\text { (ns) }\end{array}$ & $\begin{array}{l}0.24 \\
\text { (ns) }\end{array}$ & $\begin{array}{l}0.22 \\
\text { (ns) }\end{array}$ & $\begin{array}{l}0.32 \\
(\mathrm{~ns})\end{array}$ & $\begin{array}{l}0.29 \\
\text { (ns) }\end{array}$ & $\begin{array}{l}0.14 \\
\text { (ns) }\end{array}$ & $\begin{array}{l}0.24 \\
\text { (ns) }\end{array}$ & $\begin{array}{l}0.27 \\
\text { (ns) }\end{array}$ & $\begin{array}{c}0.56 \\
(* *)\end{array}$ & $\begin{array}{l}0.40 \\
\text { (ns) }\end{array}$ \\
\hline AEVR_10 & $\begin{array}{l}0.21 \\
\text { (ns) }\end{array}$ & $\begin{array}{l}0.32 \\
\text { (ns) }\end{array}$ & $\begin{array}{l}0.24 \\
\text { (ns) }\end{array}$ & $\begin{array}{c}0.43 \\
\left(^{*}\right)\end{array}$ & $\begin{array}{l}0.34 \\
\text { (ns) }\end{array}$ & $\begin{array}{l}0.21 \\
\text { (ns) }\end{array}$ & $\begin{array}{l}0.28 \\
\text { (ns) }\end{array}$ & $\begin{array}{l}0.37 \\
\text { (ns) }\end{array}$ & $\begin{array}{c}0.55 \\
(* *)\end{array}$ & $\begin{array}{c}0.49 \\
(* *)\end{array}$ \\
\hline AEVR_11 & $\begin{array}{l}0.14 \\
\text { (ns) }\end{array}$ & $\begin{array}{l}0.23 \\
\text { (ns) }\end{array}$ & $\begin{array}{l}0.16 \\
\text { (ns) }\end{array}$ & $\begin{array}{l}0.38 \\
\text { (ns) }\end{array}$ & $\begin{array}{l}0.39 \\
\text { (ns) }\end{array}$ & $\begin{array}{l}0.22 \\
\text { (ns) }\end{array}$ & $\begin{array}{l}0.24 \\
\text { (ns) }\end{array}$ & $\begin{array}{l}0.34 \\
\text { (ns) }\end{array}$ & $\begin{array}{l}0.24 \\
\text { (ns) }\end{array}$ & $\begin{array}{l}0.25 \\
\text { (ns) }\end{array}$ \\
\hline AEVR_12 & $\begin{array}{l}0.23 \\
\text { (ns) }\end{array}$ & $\begin{array}{l}0.17 \\
\text { (ns) }\end{array}$ & $\begin{array}{l}0.27 \\
(\mathrm{~ns})\end{array}$ & $\begin{array}{l}0.30 \\
\text { (ns) }\end{array}$ & $\begin{array}{c}0.50 \\
(* *)\end{array}$ & $\begin{array}{l}0.15 \\
\text { (ns) }\end{array}$ & $\begin{array}{l}0.32 \\
\text { (ns) }\end{array}$ & $\begin{array}{l}0.29 \\
\text { (ns) }\end{array}$ & $\begin{array}{l}0.37 \\
\text { (ns) }\end{array}$ & $\begin{array}{l}0.17 \\
\text { (ns) }\end{array}$ \\
\hline AEVR_13 & $\begin{array}{l}0.26 \\
\text { (ns) }\end{array}$ & $\begin{array}{l}0.19 \\
\text { (ns) }\end{array}$ & $\begin{array}{l}0.26 \\
\text { (ns) }\end{array}$ & $\begin{array}{l}0.33 \\
\text { (ns) }\end{array}$ & $\begin{array}{c}0.46 \\
\left(^{*}\right)\end{array}$ & $\begin{array}{l}0.16 \\
\text { (ns) }\end{array}$ & $\begin{array}{l}0.32 \\
\text { (ns) }\end{array}$ & $\begin{array}{l}0.28 \\
\text { (ns) }\end{array}$ & $\begin{array}{l}0.36 \\
\text { (ns) }\end{array}$ & $\begin{array}{l}0.25 \\
\text { (ns) }\end{array}$ \\
\hline AEVR_14 & $\begin{array}{l}0.21 \\
\text { (ns) }\end{array}$ & $\begin{array}{l}0.19 \\
\text { (ns) }\end{array}$ & $\begin{array}{l}0.22 \\
\text { (ns) }\end{array}$ & $\begin{array}{l}0.33 \\
\text { (ns) }\end{array}$ & $\begin{array}{l}0.38 \\
\text { (ns) }\end{array}$ & $\begin{array}{l}0.14 \\
\text { (ns) }\end{array}$ & $\begin{array}{l}0.24 \\
\text { (ns) }\end{array}$ & $\begin{array}{l}0.27 \\
\text { (ns) }\end{array}$ & $\begin{array}{c}0.48 \\
\left(^{*}\right)\end{array}$ & $\begin{array}{l}0.32 \\
\text { (ns) }\end{array}$ \\
\hline AEVR_15 & $\begin{array}{l}0.05 \\
\text { (ns) }\end{array}$ & $\begin{array}{l}0.19 \\
\text { (ns) }\end{array}$ & $\begin{array}{l}0.11 \\
\text { (ns) }\end{array}$ & $\begin{array}{l}0.32 \\
\text { (ns) }\end{array}$ & $\begin{array}{l}0.29 \\
\text { (ns) }\end{array}$ & $\begin{array}{l}0.14 \\
\text { (ns) }\end{array}$ & $\begin{array}{l}0.14 \\
\text { (ns) }\end{array}$ & $\begin{array}{l}0.27 \\
\text { (ns) }\end{array}$ & $\begin{array}{l}0.42 \\
\text { (ns) }\end{array}$ & $\begin{array}{l}0.30 \\
\text { (ns) }\end{array}$ \\
\hline AEVR_16 & $\begin{array}{c}0.43 \\
\left(^{*}\right)\end{array}$ & $\begin{array}{l}0.26 \\
0.33\end{array}$ & $\begin{array}{l}0.41 \\
0.12\end{array}$ & $\begin{array}{l}0.37 \\
0.16\end{array}$ & $\begin{array}{c}0.56 \\
(* *)\end{array}$ & $\begin{array}{l}0.21 \\
0.43\end{array}$ & $\begin{array}{c}0.44 \\
(*)\end{array}$ & $\begin{array}{l}0.31 \\
0.24\end{array}$ & $\begin{array}{c}0.44 \\
\left(^{*}\right)\end{array}$ & $\begin{array}{l}0.35 \\
0.18\end{array}$ \\
\hline AEVR_17 & $\begin{array}{l}0.11 \\
\text { (ns) }\end{array}$ & $\begin{array}{l}0.16 \\
\text { (ns) }\end{array}$ & $\begin{array}{l}0.14 \\
(\mathrm{~ns})\end{array}$ & $\begin{array}{l}0.28 \\
(\mathrm{~ns})\end{array}$ & $\begin{array}{l}0.33 \\
\text { (ns) }\end{array}$ & $\begin{array}{l}0.09 \\
\text { (ns) }\end{array}$ & $\begin{array}{l}0.17 \\
\text { (ns) }\end{array}$ & $\begin{array}{l}0.21 \\
\text { (ns) }\end{array}$ & $\begin{array}{l}0.39 \\
\text { (ns) }\end{array}$ & $\begin{array}{l}0.32 \\
(\mathrm{~ns})\end{array}$ \\
\hline AEVR_18 & $\begin{array}{l}0.26 \\
\text { (ns) }\end{array}$ & $\begin{array}{l}0.33 \\
\text { (ns) }\end{array}$ & $\begin{array}{l}0.30 \\
(\mathrm{~ns})\end{array}$ & $\begin{array}{c}0.43 \\
\left({ }^{*}\right)\end{array}$ & $\begin{array}{l}0.37 \\
\text { (ns) }\end{array}$ & $\begin{array}{l}0.24 \\
\text { (ns) }\end{array}$ & $\begin{array}{l}0.31 \\
\text { (ns) }\end{array}$ & $\begin{array}{l}0.38 \\
(\mathrm{~ns})\end{array}$ & $\begin{array}{c}0.55 \\
(* *)\end{array}$ & $\begin{array}{c}0.44 \\
\left({ }^{*}\right)\end{array}$ \\
\hline
\end{tabular}

${ }^{1}$ Significance levels: $p$-value: $\left({ }^{* * *}\right)[<0.01] ;\left(^{* *}\right)[0.01-0.05] ;\left(^{*}\right)[0.05-0.1] ;($ ns) $[>0.1]$ not significant.

Table 4. Correlation between low income and pollutants in summer (_S) and winter (_W) with significance level ${ }^{1}$.

\begin{tabular}{|c|c|c|c|c|c|c|c|c|c|c|}
\hline Pollutants & NO2_S & NO2_W & PM2.5_S & PM2.5_W & PM10_S & PM10_W & V BC_S & BC_W & BTEX_S & BTEX_W \\
\hline $\begin{array}{c}\text { Low } \\
\text { Income }\end{array}$ & $\begin{array}{c}0.68 \\
(* *)\end{array}$ & $\begin{array}{l}0.67 \\
(* *)\end{array}$ & $\begin{array}{c}0.66 \\
\left({ }^{*}\right)\end{array}$ & $\begin{array}{l}0.57 \\
(* *)\end{array}$ & $\begin{array}{c}0.47 \\
(*)\end{array}$ & $\begin{array}{c}0.56 \\
(* *)\end{array}$ & $\begin{array}{c}0.62 \\
(* *)\end{array}$ & $\begin{array}{c}0.56 \\
(* *)\end{array}$ & $\begin{array}{l}0.40 \\
\text { (ns) }\end{array}$ & $\begin{array}{c}0.52 \\
(* *)\end{array}$ \\
\hline
\end{tabular}

${ }^{1}$ Significance levels: $p$-value: $\left(^{* * *}\right)[<0.01] ;\left(^{* *}\right)[0.01-0.05] ;\left(^{*}\right)[0.05-0.1] ;($ ns) $[>0.1]$ not significant.

\section{Discussion}

Ambient air pollutants, including $\mathrm{NO}_{2}, \mathrm{PM}_{2.5}, \mathrm{PM}_{10}, \mathrm{BC}$, and $\mathrm{BTEX}$, have been shown to exacerbate asthma [6-9,16,19,20,22,23,25,51,52]. Although Calgary has relatively good air quality [39], this study shows that significant correlations exist between ambient pollutants and AEVRs, though there is seasonal variation. The correlations to AEVs acts as proxy data and suggest asthma exacerbation [9]. This study also shows that AEVs, as well as air pollutants, exhibit a distinct spatial pattern over the vast metropolitan area of Calgary. The spatial pattern of asthma emergency visits is compatible with that of the pollutants analyzed, as correlations also suggest. Pollutant concentration is generally higher in the east, northeast, and central areas of the city-that is, areas characterized by industrial land use and major traffic corridors. Pollutants such as BC and BTEX are often a result of biomass combustion and fossil fuel combustion, whereas $\mathrm{NO}_{2}$ and $\mathrm{PM}_{2.5}$ are mainly indicators of traffic pollution and $\mathrm{PM}_{10}$ often refers to dust, mold spores, and pollen [26-29]. 


\subsection{Pollutants and Seasonality}

Despite ambient pollutant concentrations being higher in the winter months than the summer months, a stronger correlation was observed between AEVs and pollutants in the summer months. Although $\mathrm{NO}_{2}$ has previously been associated with increased asthma-related visits to the emergency room, our study found the correlation between $\mathrm{NO}_{2}$ and asthma emergency visits to be significant only in summer $2016[8,9,17,18,20]$. This may be a result of the inversely related relationship between nitrogen oxides $\left(\mathrm{NO}_{\mathrm{x}}\right)$ and ozone $\left(\mathrm{O}_{3}\right)$ [53]. During the summer months, more ground level $\mathrm{O}_{3}$ is formed; studies have found that increasing concentrations of ground level $\mathrm{O}_{3}$ increase the risk of hospitalization and emergency department visits for asthma and asthma-related symptoms [53,54].

BTEX and, to a lesser extent, $\mathrm{PM}_{10}$ are frequently correlated to AEVRs in the summer. Due to the warmer weather, there may be some further inclination to partake in outdoor activity, increasingly exposing individuals to both air pollutants and allergens such as pollen. Although pollen types and concentrations vary seasonally and geographically, any kind of pollen can increase the risk of asthma-related hospital visits by 1-14\% [55]. However, exercise induced bronchoconstriction can occur in children with asthma due to exercise alone, which can also lead to hospitalizations and emergency room visits [56]. Interestingly, both $\mathrm{PM}_{10}$ and BTEX can result from biomass combustion, such as forest fires [26-28], which are a frequent occurrence in the mountains southwest of Calgary; fire smoke is known to be carried over the metropolitan area by seasonal winds $[57,58]$.

$\mathrm{PM}_{2.5}$ was the only pollutant that was consistently correlated to AEVRs in the winter months, though the correlation was rarely significant. This may be a result of increased vehicular idling or increased natural gas and fossil fuel combustion for heaters. However, it is important to note that indoor air pollutants such as dust and mold have been linked to asthma exacerbation [59-61].

\subsection{Temporal Trend}

Interestingly, the most numerous significant correlations between AEV and pollutants $\left(\mathrm{NO}_{2}\right.$, $\mathrm{PM}_{10}, \mathrm{BC}$, and BTEX) were observed during the summer of 2016. The reasons for this association are unclear; however, the summer of 2016 was unusually rainy in Calgary $[57,58]$. Forest fires were less severe than during other summers, yet the increased humidity, possibly compounded with altered temperatures, may have influenced the plant blooming season, with variation in the amount or mix of pollen in the air $[57,58]$. Additionally, Calgary experienced major floods in the summer of 2013, which may have impacted the formation of indoor and outdoor mold in the following years [62].

Overall, there was a decrease in AEVR between 2008 and 2018 in all LGAs in Calgary. Other studies have found that increasing concentrations of pollutants increase asthma exacerbation and emergency room visits as well as decreasing lung function [16-18,36]. Air pollution also decreased between 2008 and 2018; however, as seen in Figure 2, asthma exacerbation decreased drastically between 2008 and 2014 [63]. Despite the overall decreasing emergency visit rate, AEVS increased in some LGAs. The reasons for this sharp decline are unclear. However, a more expansive drug coverage was implemented in Alberta after the enactment of the National Common Drug Review process [64]. Fluticasone and Ciclesonide, inhaled corticosteroids, were added to the Alberta drug benefit program in 2007 and 2006, respectively [64]. A combination drug, salmeterol/fluticasone, has been a part of the Alberta drug benefit program since 1999 and has been considered to be both more cost effective and more effective at treating asthma [64]. It remains unclear whether the addition of the two inhaled corticosteroids could cause such a substantial decrease in AEV rates.

\subsection{Spatial Analysis}

The spatial analysis yields what appears to be the most novel and relevant results of this study. Descriptive and visual analyses show that AEV exhibits higher values in the eastern quadrants of Calgary. Consistently, Moran's I shows that AEV exhibits positive spatial autocorrelation, indicating that nearby LGAs exhibit similar AEV rates. Conversely, Getis $G$ yields null results, suggesting that 
AEVs do not tend to form spatial clusters. The combination of these three analyses suggests that AEV exhibits a spatial trend, not only visually discernible but also quantifiable and statistically significant: it consists of a gradient, increasing from the west and southwest to the east and northeast portions of the metropolitan area. This pattern is consistent with pollution patterns previously noted in the literature and is further confirmed by correlation analysis $[33,39,43,44]$. Further, spatial autocorrelation in AEV increases over the years, suggesting that the gradient is becoming more pronounced, likely indicating a growing disparity across the city. The correlation analysis between pollutants and the socioeconomic indicator tested for the regression analysis shows that the correlation between low income and any pollutant is never below 0.40 (BTEX), reaching values as high as $0.68\left(\mathrm{NO}_{2}\right)$. These results point to a strong association linking low income, high air pollution, and high AEV; these associations are linked to specific communities, with a clear gradient from the wealthier to the less fortunate portions of the city, with a widening gap in wealth, health, and air quality between west and southwest compared to east and northeast. Our analysis of asthma emergency rates and ambient air pollution over space and time was able to identify this widening gap, which should be further investigated by health authorities.

\subsection{Limitations, Novelty, and Future Work}

The primary limitation of this study was the lack of data. We could not analyze the association between AEV and pollutants in children, owing to the lack of age-specific data. The sample size was small, as AEV data were limited to 16 LGAs within the city of Calgary. Descriptive spatial analyses were conducted and presented, yet multivariate analyses such as regression analysis are problematic in a small sample. The temporal sample of AEV consisted of 11 years, which is an even smaller sample for temporal analyses. In addition, only 2015-2016 spatial pollution estimates were used to assess the association of ambient pollutants and AEV throughout the entire study period. For these reasons, this work is considered a preliminary analysis.

Within the current COVID-19 pandemic, this spatial analytical study is particularly relevant and timely, owing to its potential to identify hotspots linked to ambient air pollution and populations at greater risk. Despite its limitations, this work achieved relevant results, particularly from the spatial analysis. Specifically, pollution data are rarely available at fine scale, and estimates are not often available at the intra-urban scale. As the LUR models were developed by our research group, we can affirm with certainty that this is the first study to analyze the association of asthma and air pollution over space in this large metropolitan area. Its results will be shared with medical and nursing staff and will yield strong potential to aid the management of children and adults affected by asthma.

Further work is underway to conduct additional monitoring campaigns (currently halted by the coronavirus disease 2019 (COVID-19) pandemic) which will provide additional data to define the temporal trend of pollution. As shown in [44], the existing LUR estimates can be used in conjunction with data from the regulatory network to estimate air pollution over time and space and over a given temporal interval $[33,45]$. This work will be expanded to provide detailed spatial and temporal air quality estimates over several years.

This preliminary study yielded some very promising results. Building on these preliminary findings, we will seek permission to obtain ethical approval to analyze AEV data for different age groups and at a finer spatial and temporal resolution. For example, data at the community level, as well as seasonal and annual data, should be used; just the community and seasonal data would provide 44 temporal samples over approximately 200 spatial units, and this number could also increase if age-specific data were to be obtained. Building on these data, we will perform multivariate analyses to robustly and reliably assess the relationships identified by this preliminary study. This study will be further expanded by monitoring the effects of air pollution on asthma in children specifically. The latter analysis will involve monitoring the ambient air pollution surrounding frequently visited locations, such as place of residence, school zones, and playground locations. Moreover, particular age groups could be analyzed to determine whether age plays a role in susceptibility to asthma exacerbation by air pollution. 


\section{Conclusions}

We performed a preliminary spatial analysis of the association of asthma emergency visits (AEV) with air pollutants $\left(\mathrm{NO}_{2}, \mathrm{PM}_{2.5}, \mathrm{PM}_{10}, \mathrm{BC}\right.$, and BTEX) over the metropolitan area of Calgary, Canada. Maps and descriptive statistics show that AEV displays a discernible spatial pattern across the city. Spatial statistics (Moran's I spatial autocorrelation index and Getis G clustering index), in combination with the observed pattern, describe this pattern as a gradient, characterized by increasing AEVs from the western to the eastern portions of the city. Correlation and regression indicate that this trend is associated with air pollution and socioeconomic status. Spatial autocorrelation tests repeated over an 11-year study period (2008-2018) indicate that the gradient is becoming more pronounced, suggesting that disparities across the city are increasing over time. The association of asthma and air pollution is consistent with the location of industrial areas and major traffic corridors. Over the years, AEVs have overall decreased; however, the decline was more pronounced between 2010 and 2014. This decline did not occur consistently in all the areas of Calgary. AEV exhibited more significant associations with BTEX and $\mathrm{PM}_{10}$. Despite greater pollution levels in the winter, the association with AEV was more pronounced in the summer. The novelty of the study is the spatial analytical approach based on fine-scale pollution estimates.

Supplementary Materials: The following are available online at http://www.mdpi.com/2073-4433/11/10/1066/s1, Table S1: Spatial distribution of AEV and AEVR for each year of the study period, Table S2: Regression analysis for AEV2016 on all summer and winter pollutants.

Author Contributions: Conceptualization, S.B., C.C.-B., R.S. and I.C.; Methodology, S.B. and C.C.-B. Software, S.B. and C.C.-B.; Validation, S.B. and C.C.-B.; Formal Analysis, S.B. and C.C.-B.; Investigation, S.B., C.C.-B., R.S., I.C., and R.W.; Resources, R.S., I.C., C.C.-B., and S.B.; Data Curation, S.B., C.C.-B., R.S., and I.C.; Writing-Original Draft Preparation, S.B. and C.C.-B; Writing-Review \& Editing, S.B., C.C.-B., R.S., I.C. and R.W.; Visualization, S.B., R.S. and I.C.; Supervision, S.B.; Project Administration, S.B.; Funding Acquisition, S.B., C.C.-B., and R.S. All authors have read and agreed to the published version of the manuscript.

Funding: This research received no external funding.

Acknowledgments: We thank Alberta Innovates for the Summer Research Studentship Award in support of the project "Spatial Monitoring of Air Pollution in Urban Calgary for Assessing Possible Health Impacts", as well as the Canadian Institutes for Health Research, CIHR Institute for Population and Public Health, and the O'Brien Institute for Public Health for funding the project "Walk smart, breathe smart". We acknowledge our colleagues and members of the OIPH Geography of Health Study Group for their insightful thoughts and stimulating discussions. We are grateful to Brian Moorman for making introductions that led to our collaboration. We finally thank the anonymous reviewers for their comments and constructive criticism.

Conflicts of Interest: The authors declare no conflict of interest.

\section{References}

1. Holgate, S.T.; Wenzel, S.; Postma, D.S.; Weiss, S.T.; Renz, H.; Sly, P.D. Asthma. Nat. Rev. Dis. Primers. 2014, 1, 15025. [CrossRef]

2. Understanding Asthma. Available online: https://asthma.ca/get-help/understanding-asthma/ (accessed on 2 September 2020).

3. Asthma. Available online: https://www.canada.ca/en/public-health/services/diseases/asthma.html (accessed on 2 September 2020).

4. Asthma. Available online: https://www.albertahealthservices.ca/info/Page15627.aspx (accessed on 11 August 2020).

5. Bosonea, A.M.; Sharpe, H.; Wang, T.; Bakal, J.; Befus, D.; Svenson, L.; Vliagoftis, H. Developments in asthma incidence and prevalence in Alberta between 1995 and 2015. Allergy Asthma Clin. Immunol. 2020. under review.

6. Asthma-Age-Sex Specific Incidence Rate. Available online: http://www.ahw.gov.ab.ca/IHDA_Retrieval/ redirectToURL.do?cat $=6 \&$ subCat $=1049$ (accessed on 31 August 2020).

7. Tétreault, L.F.; Doucet, M.; Gamache, P.; Fournier, M.; Brand, A.; Kosatsky, T.; Smargiassi, A. Childhood exposure to ambient air pollutants and the onset of asthma: An administrative cohort study in Québec. Environ. Health Perspect. 2016, 124, 1276-1282. [CrossRef] [PubMed] 
8. Zheng, X.Y.; Ding, H.; Jiang, L.N.; Chen, S.W.; Zheng, J.P.; Qiu, M.; Zhou, Y.X.; Chen, Q.; Guan, W.J. Association between air pollutants and asthma emergency room visits and hospital admissions in time series studies: A systematic review and meta-analysis. PLoS ONE 2015, 10, e0138146. [CrossRef] [PubMed]

9. Bouazza, N.; Foissac, F.; Urien, S.; Guedj, R.; Carbajal, R.; Tréluyer, J.M.; Chappuy, H. Fine particulate pollution and asthma exacerbations. Arch. Dis. Child. 2018, 103, 828-831. [CrossRef]

10. Rosychuk, R.J.; Ospina, M.; Zhang, J.; Leigh, R.; Cave, A.; Rowe, B.H. Sex differences in outcomes after discharge from Alberta emergency departments for asthma: A large population-based study. J. Asthma 2018, 55, 817-825. [CrossRef] [PubMed]

11. Requia, W.J.; Adams, M.D.; Koutrakis, P. Association of $\mathrm{PM}_{2.5}$ with diabetes, asthma, and high blood pressure incidence in Canada: A spatiotemporal analysis of the impacts of the energy generation and fuel sales. Sci. Total Environ. 2017, 584-585, 1077-1083. [CrossRef]

12. Villamizar, L.A. Outdoor Air Pollution and Children's Asthma in the Census Metropolitan Area of Edmonton, Alberta: The Influence of Place of Residence and Socioeconomic Position. Ph.D. Thesis, University of Alberta, Edmonton, AB, Canada, 2016.

13. Kozyrskyj, A.L.; Kendall, G.E.; Jacoby, P.; Sly, P.D.; Zubrick, S.R. Association between socioeconomic status and the development of asthma: Analyses of income trajectories. Am. J. Public Health 2010, 100, 540-546. [CrossRef]

14. Almqvist, C.; Pershagen, G.; Wickman, M. Low socioeconomic status as a risk factor for asthma, rhinitis and sensitization at 4 years in a birth cohort. Clin. Exp. Allergy 2005, 35, 612-618. [CrossRef]

15. Bacon, S.L.; Bouchard, A.; Loucks, E.B.; Lavoie, K.L. Individual-level socioeconomic status is associated with worse asthma morbidity in patients with asthma. Respir. Res. 2009, 10, 125. [CrossRef]

16. Cakmak, S.; Dales, R.E.; Judek, S. Respiratory health effects of air pollution gases: Modification by education and income. Arch. Environ. Occup. Health 2006, 61, 5-10. [CrossRef] [PubMed]

17. Castner, J.; Guo, L.; Yin, Y. Ambient air pollution and emergency department visits for asthma in Erie County, New York 2007-2012. Int. Arch. Occup. Environ. Health 2018, 91, 205-214. [CrossRef] [PubMed]

18. Orellano, P.; Quaranta, N.; Reynoso, J.; Balbi, B.; Vasquez, J. Effect of outdoor air pollution on asthma exacerbations in children and adults: Systematic review and multilevel meta-analysis. PLoS ONE 2017, 12, e0174050. [CrossRef] [PubMed]

19. Khreis, H.; Kelly, C.; Tate, J.; Parslow, R.; Lucas, K.; Nieuwenhuijsen, M. Exposure to traffic-related air pollution and risk of development of childhood asthma: A systematic review and meta-analysis. Environ. Int. 2017, 100, 1-31. [CrossRef]

20. Khreis, H.; Nieuwenhuijsen, M.J. Traffic-related air pollution and childhood asthma: Recent advances and remaining gaps in the exposure assessment methods. Int. J. Environ. Res. Public Health 2017, 14, 312. [CrossRef]

21. Gauderman, W.J.; Vora, H.; McConnell, R.; Berhane, K.; Gilliland, F.; Thomas, D.; Lurmann, F.; Avol, E.; Kunzli, N.; Jerrett, M.; et al. Effect of exposure to traffic on lung development from 10 to 18 years of age: A cohort study. Lancet 2007, 369, 571-577. [CrossRef]

22. Rosenlund, M.; Forastiere, F.; Porta, D.; De Sario, M.; Badaloni, C.; Perucci, C.A. Traffic-related air pollution in relation to respiratory symptoms, allergic sensitisation and lung function in schoolchildren. Thorax 2009, 64, 573-580. [CrossRef]

23. Dell, S.D.; Jerrett, M.; Beckerman, B.; Brook, J.R.; Foty, R.G.; Gilbert, N.L.; Marshall, L.; Miller, J.D.; To, T.; Walter, S.D.; et al. Presence of other allergic disease modifies the effect of early childhood traffic-related air pollution exposure on asthma prevalence. Environ. Int. 2014, 65, 83-92. [CrossRef]

24. Hesam, M.; Shakerkhatibi, M.; Samadi, M.T.; Poorolajal, J.; Rahmani, A.; Rafieemehr, H. Long-term exposure to outdoor VOCs and lung function in urban adults: A cross-sectional study in Tabriz an industrialized city in the northwest of Iran. Hum. Ecol. Risk Assess. 2020, 26, 1512-1528. [CrossRef]

25. Clark, N.A.; Demers, P.A.; Karr, C.J.; Koehoorn, M.; Lencar, C.; Tamburic, L.; Brauer, M. Effect of early life exposure to air pollution on development of childhood asthma. Environ. Health Perspect. 2010, 118, 284-290. [CrossRef]

26. Inhalable Particulate Matter and Health $\left(\mathrm{PM}_{2.5}\right.$ and $\left.\mathrm{PM}_{10}\right)$. Available online: https://ww2.arb.ca.gov/ resources/inhalable-particulate-matter-and-health (accessed on 1 September 2020). 
27. Dehghani, M.; Fazlzadeh, M.; Sorooshian, A.; Tabatabaee, H.R.; Miri, M.; Baghani, A.N.; Delikhoon, M.; Mahvi, A.H.; Rashidi, M. Characteristics and health effects of BTEX in a hot spot for urban pollution. Ecotoxic Environ. Saf. 2018, 155, 133-143. [CrossRef] [PubMed]

28. Volatile Organic Compounds. Available online: https://www.lung.org/clean-air/at-home/indoor-airpollutants/volatile-organic-compounds (accessed on 3 September 2020).

29. Black Carbon Research. Available online: https://www.epa.gov/air-research/black-carbon-research (accessed on 3 September 2020).

30. Particulate Matter Literature Review. Available online: http://www.burncohowesound.com/wp-content/ uploads/2016/08/9.1_E_APP\%20PM\%20Literature\%20Review.pdf (accessed on 2 September 2020).

31. Nurvatov, U.B.; Tagiyeva, N.; Semple, S.; Devereux, G.; Sheikh, A. Volatile organic compounds and risk of asthma and allergy: A systematic review. Eur. Respir. Rev. 2015, 24, 92-101. [CrossRef] [PubMed]

32. Dissemination Block. Available online: https://www150.statcan.gc.ca/n1/pub/92-195-x/2011001/geo/db-id/ db-id-eng.htm (accessed on 23 September 2020).

33. Bertazzon, S.; Couloigner, I.; Underwood, F.E. Spatial land use regression of nitrogen dioxide over a 5-year interval in Calgary, Canada. Int. J. Geogr. Inf. Sci. 2019, 33, 1335-1354. [CrossRef]

34. Population and Dwelling Count Highlight Tables, 2016 Census. Available online: https://www12.statcan.gc. ca/census-recensement/2016/dp-pd/hlt-fst/pd-pl/Table.cfm?Lang=Eng\&T=301\&S=3\&O=D (accessed on 13 June 2020).

35. City of Calgary Statistics Profile. Available online: http://www.municipalaffairs.alberta.ca/cfml/ MunicipalProfiles/index.cfm?fuseaction=BasicReport\&MunicipalityType=CITY\&stakeholder=46\& profileType=STAT (accessed on 13 June 2020).

36. Calgary Facts. Available online: https://www.lifeincalgary.ca/moving/calgary-facts (accessed on 13 June 2020).

37. Where is Calgary? Available online: https://calgaryeconomicdevelopment.com/why-calgary/where-iscalgary/where-is-calgary/ (accessed on 13 June 2020).

38. Average Annual Wind Speed at Canadian Cities. Available online: https://www.currentresults.com/Weather/ Canada/Cities/wind-annual-average.php (accessed on 13 June 2020).

39. Bertazzon, S.; Shahid, R. Schools, air pollution, and active transportation: An exploratory spatial analysis of Calgary, Canada. Int. J. Environ. Res. Public Health 2017, 14, 834. [CrossRef]

40. Chapter 5 Airport Climatology Alberta. Available online: https://www.navcanada.ca/EN/media/Publications/ Local\%20Area\%20Weather\%20Manuals/LAWM-Prairies-5-EN.pdf (accessed on 3 September 2020).

41. Official Standard Geographic Areas. Available online: https://open.alberta.ca/dataset/a14b50c9-94b24024-8ee5-c13fb70abb4a/resource/70fd0f2c-5a7c-45a3-bdaa-e1b4f4c5d9a4/download/Official-StandardGeographic-Area-Document.pdf (accessed on 28 July 2020).

42. Bertazzon, S.; Johnson, M.; Eccles, K.; Kaplan, G.G. Accounting for spatial effects in land use regression for urban air pollution modelling. Spat. Spatio-Temporal Epidemiol. 2015, 14-15, 9-21. [CrossRef]

43. Bertazzon, S.; Underwood, F.; Johnson, M.; Zhang, J. Land use regression of particulate matter in Calgary, Canada. In Proceedings of the Ninth International Conference on Geographic Information Science, Montreal, QC, Canada, 27-30 September 2016. [CrossRef]

44. Bertazzon, S.; Couloigner, I. Exploratory spatial analysis of air pollution over a large metropolitan area. Riv. Geogr. Ital. 2018, 125, 525-548.

45. Liu, X.; Bertazzon, S. Fine scale spatiotemporal modelling of urban air pollution. In Geographic Information Science, Proceedings of the Ninth International Conference on Geographic Information Science. GIScience 2016, Montreal, QC, Canada, 27-30 September 2016; Miller, J., O'Sullivan, D., Wiegand, N., Eds.; Springer: Berlin, Germany, 2016; Volume 9927, pp. 210-224.

46. Getis, A.; Ord, J.K. The analysis of spatial association by use of distance statistics. Geogr. Anal. 1992, 24, 189-206. [CrossRef]

47. Getis, A. A history of the concept of spatial autocorrelation: A geographer's perspective. Geogr. Anal. 2008, 40, 297-309. [CrossRef]

48. Burt, J.; Barber, G.; Rigby, D.L. Elementary Statistics for Geographers, 3rd ed.; Guilford Press: New York, NY, USA, 2009.

49. Anselin, L. Spatial Econometrics: Methods and Models; Kluwer Academic Publishers: Dordrecht, The Netherlands, 1998. 
50. Wind History for CYYC: Calgary International, Alta. Available online: http://windhistory.com/station.html? CYYC (accessed on 26 September 2020).

51. Rumchev, K.; Spickett, J.; Bulsara, M.; Phillips, M.; Stick, S. Association of domestic exposure to volatile organic compounds with asthma in young children. Thorax 2004, 59, 746-751. [CrossRef]

52. Hulin, M.; Caillaud, D.; Annesi-Maesano, I. Indoor air pollution and childhood asthma: Variations between urban and rural areas. Indoor Air 2010, 20, 502-514. [CrossRef]

53. Roberts-Semple, D.; Song, F.; Gao, Y. Seasonal characteristics of ambient nitrogen oxides and ground-level ozone in metropolitan northeastern New Jersey. Atmos. Pollut. Res. 2012, 3, 247-257. [CrossRef]

54. Byers, N.; Ritchey, M.; Vaidyanathan, A.; Brandt, A.J.; Yip, F. Short-term effects of ambient air pollutants on asthma-related emergency department visits in Indianapolis, Indiana, 2007-2011. J. Asthma 2016, 53, 245-252. [CrossRef] [PubMed]

55. $\quad$ Erbas, B.; Jazayeri, M.; Lambert, K.A.; Katelaris, C.H.; Prendergast, L.A.; Tham, R.; Parrodi, M.J.; Davies, J.; Newbigin, E.; Abramson, M.J.; et al. Outdoor pollen is a trigger of child and adolescent asthma emergency department presentations: A systematic review and meta-analysis. Allergy 2018, 73, 1632-1641. [CrossRef] [PubMed]

56. Côté, A.; Turmel, J.; Boulet, L.P. Exercise and Asthma. Semin Respir Crit. Care Med. 2018, 39, 19-28. [CrossRef] [PubMed]

57. Mirzaei, M.; Bertazzon, S.; Couloigner, I. Modeling wildfire smoke pollution by integrating land use regression and remote sensing data: Regional multi-temporal estimates for public health and exposure models. Atmosphere 2018, 9, 335. [CrossRef]

58. Mirzaei, M.; Bertazzon, S.; Couloigner, I.; Farjad, B.; Ngom, R. Estimation of local daily PM $_{2.5}$ concentration during wildfire episodes: Integrating MODIS AOD with multivariate linear mixed effect (LME) models. Air Qual. Atmos. Health 2020, 13, 173-185.

59. Tischer, C.; Chen, C.M.; Heinrich, J. Association between domestic mould and mould components, and asthma and allergy in children: A systematic review. Eur. Respiry J. 2011, 38, 812-824. [CrossRef]

60. Tischer, C.G.; Hohmann, C.; Thiering, E.; Herbarth, O.; Müller, A.; Henderson, J.; Granell, R.; Fantini, M.P.; Luciano, L.; Bergström, A.; et al. Meta-analysis of mould and dampness exposure on asthma and allergy in eight European birth cohorts: An ENRIECO initiative. Allergy 2011, 66, 1570-1579. [CrossRef]

61. Jeedrychowski, W.; Maugeri, U.; Zembala, M.; Perzanowski, M.S.; Hajto, B.; Flak, E.; Mróz, E.; Jacek, R.; Sowa, A.; Perera, F.P. Risk of wheezing associated with house-dust mite allergens and indoor air quality among three-year-old children. Kraków inner city study. Int. J. Occup. Med. Environ. Health 2007, 20, 117-126. [CrossRef]

62. Eccles, K.M.; Checkley, S.; Sjogren, D.; Barkema, H.W.; Bertazzon, S. Lessons learned from the 2013 Calgary flood: Assessing risk of drinking water well contamination. Appl. Geogr. 2017, 80, 78-85. [CrossRef]

63. Gamble, J.M.; Eurich, D.T.; Johnson, J.A. A comparison of drug coverage in Alberta before and after the introduction of the national common drug review process. Healthc. Policy 2010, 6, e117-e144. [CrossRef] [PubMed]

64. Pieters, W.R.; Wilson, K.K.; Smith, H.C.; Tamminga, J.J.; Sondhi, S. Salmeterol/fluticasone propionate versus fluticasone propionate plus montelukast: A cost-effective comparison for asthma. Treat Respir. Med. 2005, 4, 129-138. [CrossRef] [PubMed]

(C) 2020 by the authors. Licensee MDPI, Basel, Switzerland. This article is an open access article distributed under the terms and conditions of the Creative Commons Attribution (CC BY) license (http://creativecommons.org/licenses/by/4.0/). 